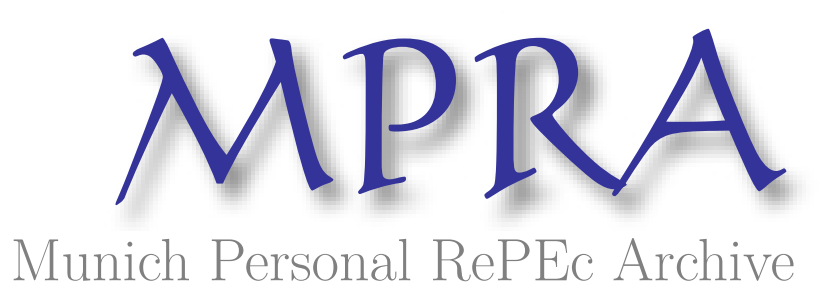

\title{
Predicting gold ores price
}

Kitov, Ivan

IDG RAS

23 June 2009

Online at https://mpra.ub.uni-muenchen.de/15873/

MPRA Paper No. 15873, posted 24 Jun 2009 00:05 UTC 


\title{
Predicting gold ores price
}

Ivan O. Kitov

\begin{abstract}
It was demonstrated that gold ores price can be predicted at a several year horizon. The prediction consists of three steps. First, we show that the difference between producer price index and the index for gold ores is characterized by the presence of sustainable mid-term trends. Second, the evolution of the difference is predicted at a five to ten-year horizon. Considering the PPI to be practically constant over the next decade, the above difference provides a direct prediction of the price index for gold ores.
\end{abstract}

Key words: gold ores, prediction, PPI

JEL classification: E3, G1 


\section{Introduction}

Gold price has been in the centre of vivid discussions since the very beginning of economics as a science. Every recession since 1971 made these discussions severe. A good portion of the disputants usually demand the return to the Gold Standard, or at least to a system similar to that established by the Bretton Woods Agreements. However, this view is not shared by the mainstream economists considering gold as an important but standard commodity. Central banks in many countries held large gold reserves as an alternative to fiat money. Such gold reserves are vulnerable to high-amplitude oscillations in gold price as observed in the past. Therefore, the future evolution of gold price is one of the highest priorities for market forecasters.

In this paper we demonstrate that gold ores price can be predicted at a several year horizon. The prediction consists of three steps. First, we demonstrate that the difference between producer price index, PPI, and the producer index for gold ores is characterized by the presence of sustainable trends. Second, we predict the difference at a five to ten-year horizon. Finally, it is demonstrated that the PPI will be practically constant over the next decade. Therefore, the above difference provides a direct prediction of the price index for gold ores.

\section{Linear trends in producer price indices}

It was found that the difference between the overall producer price index, PPI, and individual subcategories of the PPI is characterized by the presence of sustainable trends (Kitov, Kitov, 2009b). Similar trends were initially revealed in consumer price indices (Kitov, Kitov, 2008). Therefore, the presence of sustainable (linear and nonlinear) trends is an inherent feature of consumer and producer prices.

For gold ores price, this feature is also observed. Figure 1 demonstrates the difference between the PPI and the price index for gold ores (both variables retrieved on May 22, 2009 from the Bureau of Labor Statistics web-site: http://www.bls.gov/data). Notice that the index for gold ores was started in 1985. The difference has two distinct quasi-linear branches: between 1988 and 2001 (June), and from 2001 to 2008 (January). Red and blue lines highlight segments between 1988 and 2001, and from 2001 to 2008, respectively. Corresponding linear regression lines in Figure 1 have slopes of 4.7 and -11, respectively.

The presence of linear trends in the difference between the PPI and the index for gold ores is now a fact. However, it describes the past rather than foresees the future evolution. So, second step is less trivial and is based on an assumption that the presence of sustainable trends will last in the years to come. 


\section{Predicting gold ores price}

After 2008, a period of high volatility in the difference has been observed. This period is related to the turn to a new trend after 2008. A naïve assumption about the new trend is that it will repeat the trend observed between 2001 and 2008 but with an opposite sign. Actual trend may be different but inevitably with a positive slope. Here, we do not consider any other option except the naïve one. So, the green line predicts the evolution of the difference after 2008. Because the green line has a positive slope the index for gold will lag behind the PPI since 2009. According to our assumption, the rate of the deviation from the PPI will be +11 units of index per year.

However, this lag is only a relative, not absolute one. Thus, we do not know where the index for gold ores will go, if we do not know how the PPI will grow. For example, Figure 2 shows that the PPI has been growing since 1985, but the difference in Figure 1 has different slopes before and after 2001. In other words, the growth in the difference after 2009 does not indicate that the index for gold ores will decline. The decline will happen only in the case if the PPI will grow at a rate lower than 11 units of index per year. Hence, the question is how fast the PPI will grow?

We have answered this question several years ago. After 2008, inflation in the United States will be falling down to and then below zero (Kitov, 2006ab; Kitov, Kitov, Dolinskaya, 2007). Accordingly, the PPI will not be growing during the next 5 to 10 years, after it recovers by 20 units by the end of 2009 due to increasing oil price (Kitov, 2009; Kitov, Kitov, 2009a).

So, now we can refer the index for gold ores to the constant PPI since 2010. Without loss of generality, we put the 2010 level of PPI at 190. Then, the index for gold ores will fall from 230 units in 2008 to 165 in 2015 . Figure 2 illustrates the prediction - the price for gold ores will drop by $\sim 75$ units or by $75 / 230=0.33$ or $33 \%$.

\section{Conclusion}

The difference between the PPI and the price index for gold ores is characterized by the presence of two distinct segments with sustainable quasi-linear trends between 1988 and 2008, with a turning point in 2001. It is likely that the difference in the next 5 to 10 years will show similar behavior, i.e. a new robust trend will be observed. To continue the previously observed pattern, the new trend should be characterized by a positive slope, which absolute value can not be currently determined.

For the sake of simplicity, it is assumed that the new trend will repeat the previous one but with an opposite sign. At the same time, the PPI will not be growing during the next decade because inflation in the US will approach the zero rate. As a result, gold price will be falling by $\sim 11$ units of index per year during the next seven years. If the slope will be higher than 11 units 
per year, the next trend will be shorter in duration, and vice versa. The absolute change of about 75 units is likely to be the same for any slope.

Apparently, the above estimates are only crude ones and actual duration and slop will be determined only in several years. However, the fall in gold price by about $35 \%$ is very likely, if the link between the PPI and the index for gold ores will retain.

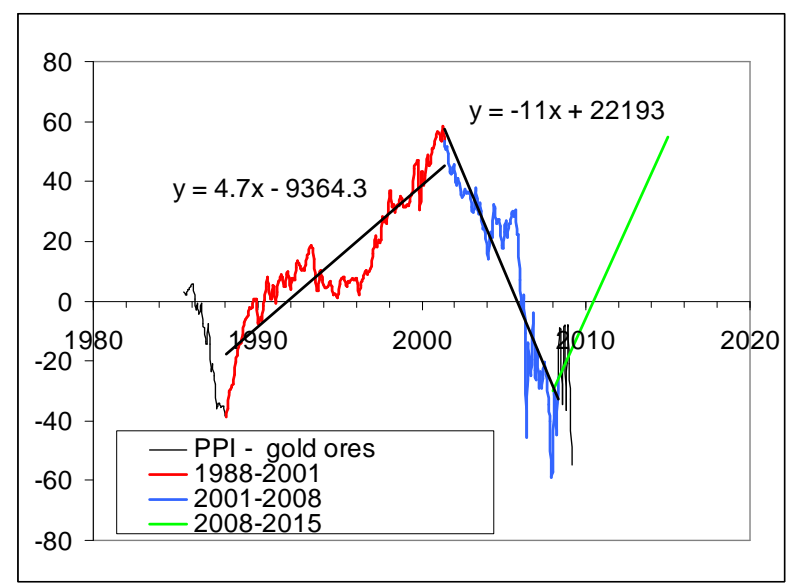

Figure 1. Evolution of the difference between the PPI and the price index for gold ores between 1985 and 2009. Red and blue lines highlight segments between 1988 and 2001, and from 2001 to 2008, respectively. Green line predicts the evolution of the difference after 2008, as a mirror reflection of the linear trend between 2001 and 2008.

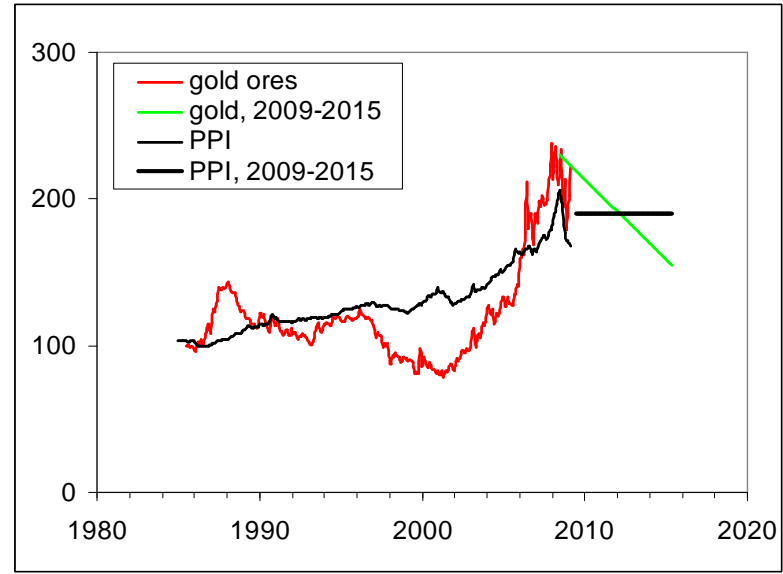

Figure 2. Evolution of the PPI and the index for gold ores since 1985. Green line - the prediction of the index for gold ores between 2008 and 2015. Thick black line - the PPI at constant level between 2010 and 2015.

\section{References}

Kitov, I. (2006a). Inflation, unemployment, labor force change in the USA, Working Papers 28, ECINEQ, Society for the Study of Economic Inequality, http://www.ecineq.org/milano/WP/ECINEQ2006-28.pdf

Kitov, I., (2006b). Exact prediction of inflation in the USA, MPRA Paper 2735, University Library of Munich, Germany, http://mpra.ub.uni-muenchen.de/2735/01/MPRA_paper_2735.pdf

Kitov, I., Kitov, O., (2008). Long-Term Linear Trends In Consumer Price Indices, Journal of Applied Economic Sciences, Spiru Haret University, Faculty of Financial Management and Accounting Craiova, vol. 3(2(4)_Summ), pp. 101-112.

Kitov, I., (2009). ConocoPhillips and Exxon Mobil stock price, MPRA Paper 15334, University Library of Munich, Germany, http://mpra.ub.uni-muenchen.de/15334/01/MPRA_paper_15334.pdf 
Kitov, I., Kitov, O., (2009a). A fair price for motor fuel in the United States, MPRA Paper 15039, University Library of Munich, Germany, http://mpra.ub.uni-muenchen.de/15039/01/MPRA_paper_15039.pdf

Kitov, I., Kitov, O., (2009b). Sustainable trends in producer price indices, Journal of Applied Research in Finances, (in press). (Working paper is available: http://mpra.ub.uni-muenchen.de/15194/01/MPRA_paper_15194.pdf)

Kitov, I., Kitov, O., Dolinskaya, S., (2007). Inflation as a function of labor force change rate: cointegration test for the USA, MPRA Paper 2734, University Library of Munich, Germany, http://mpra.ub.unimuenchen.de/2734/01/MPRA_paper_2734.pdf 